DOI: 10.21625/resourceedings.v2i3.634

\title{
The role of Cloisters in Historical Cities
}

\author{
Luigi Maffei ${ }^{1}$, Massimiliano Masullo ${ }^{1}$, Roxana Adina Toma ${ }^{1}$, Danila Jacazzi ${ }^{1}$ \\ ${ }^{1}$ Università degli Studi della Campania, Department of Architecture and Industrial Design, Aversa, Italy
}

\section{Email: luigi.maffei@unicampania.it}

\begin{abstract}
Over the centuries religious architecture had a significant role in social and cultural life of people. In the past sacred architectures with their silent spaces were symbolic sites were the "voice" of God was invoked by religious who dedicated most of their life to prayer and spiritual readings.

Among them, the cloisters, with their typical architectural conformation of open-air space protected by galleries or corridors, enriched by fountains and gardens had a relevant role also for their restorativeness' capability. They were used as healing places where body, mind and spirit could benefit from the surrounding environment.

Nowadays they are still attended by men of faith, pilgrims and religious believers but also, simply, by people in searching of quietness. Their sight on the sky, the greenery and the water, and their cultural elements still affects strongly the physiological and emotional restoration process of the people and, in overcrowded cities where green areas misses, they can represent a new resource. Recent studies highlighted the possibility to use them as pockets of quiet. The paper describes their diffusion in the urban tissue of some cities in Campania and their main characteristics.
\end{abstract}

(C) 2019 The Authors. Published by IEREK press. This is an open access article under the CC BY license (https://creativecommons.org/licenses/by/4.0/).

\section{Keywords}

Cloisters, Restoration, Quiet places;

\section{Introduction}

Over the centuries religious architecture had a significant role in social and cultural life of people. In the Middle Ages a lot of monasteries, especially the Benedictine ones, were founded widely throughout Western Europe. They were built following the Rule of Saint Benedict and were encouraged to be self-sufficient (Horn, 1973) and to be able to care for themselves and for the surrounding communities. For these reasons the architecture of the monastery had to be functional (Ponzetti, 2014) and all spaces were organized around the cloister dedicated to communal living where the monks and nuns prayed and worked together.

A cloister is, typically, a square courtyard surrounded by a covered walkway with a central space enriched by the presence of greenery or fountains. They had a lot of different functions: here the monks and the nuns, that followed a precisely fixed daily life, could dedicate themselves to prayer, spiritual readings and meditation or even to other intellectual activities as the transcription of manuscripts. One of the best examples of the multifunctional role of the cloisters (Rodrigues, 2015) can be the eight cloisters of the Convent of Christ in Tomar located in Portugal. Here it is possible recognize the Cemetery cloister, the Washing cloister, the Bakery cloister, the Hostel cloister, the Needs cloister and the Great cloister where the procession of Corpus Christi took place. Furthermore, a perfect example of monastic life's organization can be the royal monastery of Santa Maria of Poblet in south of Catalonia (Mallarch, 2014). Founded in the 12th century, the monastery still preserves its ancient function and the three cloisters are even 
now used by the monastic community as places of peacefulness to meditate, walk in silence and read the rule of Saint Benedict at twilight. In the recent years the gardens of the main cloister were restored but the characteristics of calm and tranquility have been kept through the flower arrangements well thought to help meditation and evoke the spiritual symbolism.

In the past, cloisters were attended not only by men of faith, but also by pilgrims, religious believers and the surrounding communities in search of medical and spiritual advices. In the Middle Ages according to the rule of Saint Benedict the monasteries had an infirmitorium to take care of sick and poor (Riva, 2013). Over the time the sacred enclosures (Alt, 2017) were conceived as healing gardens where body, mind and spirit could benefit from different elements (grass, water, medicinal plants and their sight on the sky) and where all the visitors could find tranquility and heal.

Even today it is possible to find an atmosphere of peace in the cloisters and recent studies highlighted the possibility to recover part of their original functions and use them for their restorativeness' capability (Fernandez et al., 2014) (Maffei et al., 2017, 2018). Inside the cloisters there is an impressive harmony promoted by the possibility of walking, enjoying the perfume and the colors of the garden, listening the sound of water and by the chance of being amazed by the artistic and cultural elements.

The Italian territory is characterized by the presence of numerous cloisters. Almost all ancient cities preserve some cloisters which are rich in art, plant life and in most cases characterized by the presence of fountains or other architectural elements that use water. For all these features and for their position well sheltered from nearby trafficked areas and their accessibility, they have all the qualities to be used by people in search of quietness for their restorative needs.

The paper describes the main characteristics, the potentialities and the diffusion of Cloisters in the urban historical tissue of two cities in Campania, Naples and Aversa.

\section{Cloister as healing garden: main characteristics and their diffusion in Naples and Aversa, two important historical cities in Campania.}

Historically cloisters have always been important as places dedicated to healing. Their own architectural shape conveys in that direction since they are usually rich in vegetation, water and elements of cultural value.

Different studies highlighted the importance of nature in human wellbeing (Keniger et al., 2013). Green and blue spaces have positive effects on individuals emotional state improving social and recreational activities and reducing the stress of everyday life (De Bell et al., 2017). On the other side Cultural Heritage (Dodd \& Jones, 2014) can stimulate people to try feelings of belonging to a place, encourage interactivity and influence mood, self-worth or general sense of wellbeing improving the life satisfaction and its quality.

\subsection{Naples}

Naples' contemporary urban tissue with its historical buildings and its ancient streets preserves the elements of different eras. The old city centre is today part of the list of UNESCO World Heritage Sites and count about 100 cloisters.

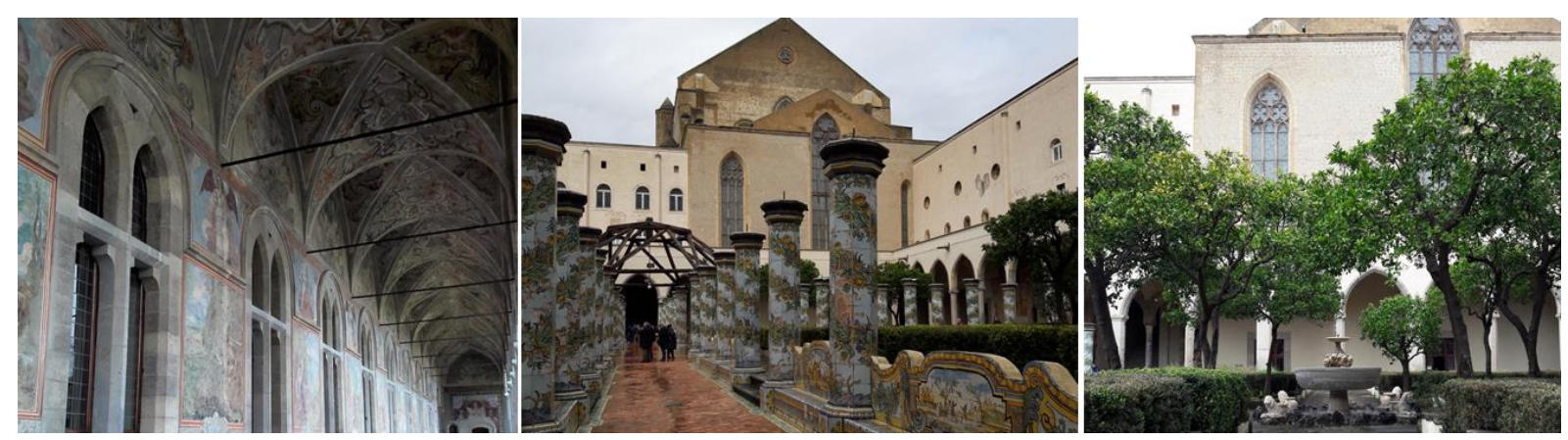

Figure 1. Cloister of the Clarisse in Santa Chiara Monastery, Naples. 
In the historic city centre is possible find different cloisters particularly significant for their gardens. One of the most well-known cloisters is the Maiolica Cloister (Cloister of the Clarisse) part of the Santa Chiara Monastery. It was redesigned in part by Domenico Antonio Vaccaro who left the original medieval plan. Its garden enriched by marble fountains and surrounded by an ambulacrum decorated with baroque frescoes was used in earlier times by the nuns to meditate and enjoy the view.
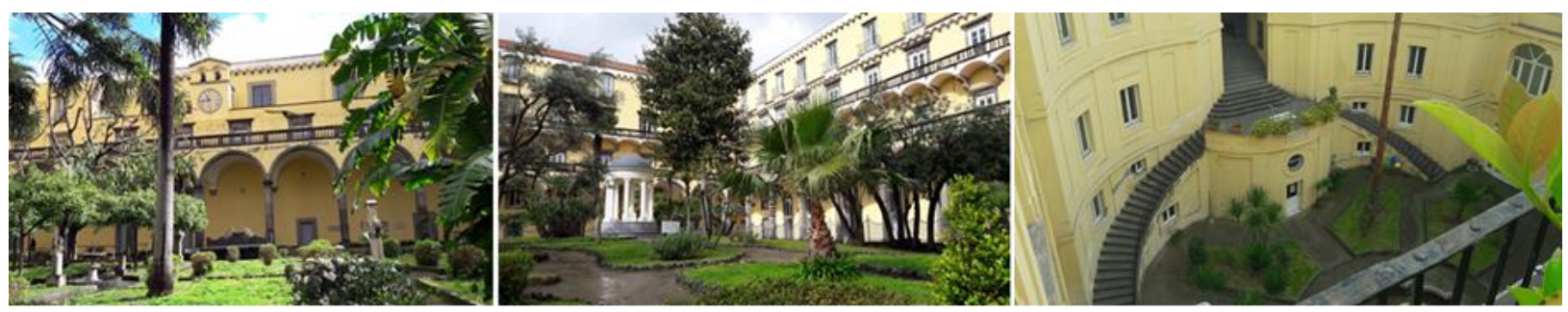

Figure 2. Upper (left, middle) and lower (right) Cloister of Saints Marcellino and Festo, Naples.

Well known for its botanical garden is also the main Cloister of Saints Marcellino and Festo that captures the attention not only for the surrounding greenness, but also for the presence of historical cultural elements like the archaeological finds, the majolica dome of San Marcellino church, the beautiful fountains and the staircase in the lower cloister.

In the same area is possible to find the Monastery of Saints Severino and Sossio with the Marble cloister whose garden is bordered by 24 arches supported by columns of Carrara marble, the Novitiate Cloister with a rectangular plan surrounded by arcades and the Cloister of the Platano whose name derives from the centuries-old plane tree placed in the center of the garden bordered by a portico decorated with frescoes on the life of Saint Benedict.

The Cloisters of Girolamini presents both green and blue elements since the cloister of the Orange Grove is attractive for the great number of orange trees while the Majolica cloister is known for the ancient meridiana with a six- hour time system and for the well in the middle enriched by an iron structure.

Other important cloisters for their history are the Cloister of San Lorenzo Maggiore which has undergone many transformations over the centuries, the three Cloisters of San Domenico Maggiore (Cloister of Saint Thomas, Cloister of the statues and the large cloister), the Cloister of Santa Maria delle Grazie known also as "Cloister of Motherhood" due to the inscription placed at the entrance for all women waiting for a child who could find refuge in the religious complex.

The cloisters of Santa Patrizia, Sant'Andrea delle Dame, San Giovanniello and the cloister of San Pietro Martire are all ancient buildings that today host faculties. The last one is particularly significant for its water system that was able to convey the water in any wing of the cloister and outside towards four public fountains. Also, the Cloister of San Gregorio Armeno is relevant for its water system and for the statues realized by Andrea Bottiglieri (Costa, 1996).

\subsection{Aversa}

The Norman city of Aversa, as Naples has a very important city centre, with historical buildings and cloisters spread within in the urban fabric.

One of the most important is the Cloister of San Francesco which was widened in the 16th century, but today it still preserves in its current configuration, traces of the intersection of Gothic and Renaissance structures on the north side. The cloister is surrounded by a covert walkway where is possible to admire the Byzantine and the Renaissance frescoes and its garden is rich in greenery and presents a water well. 

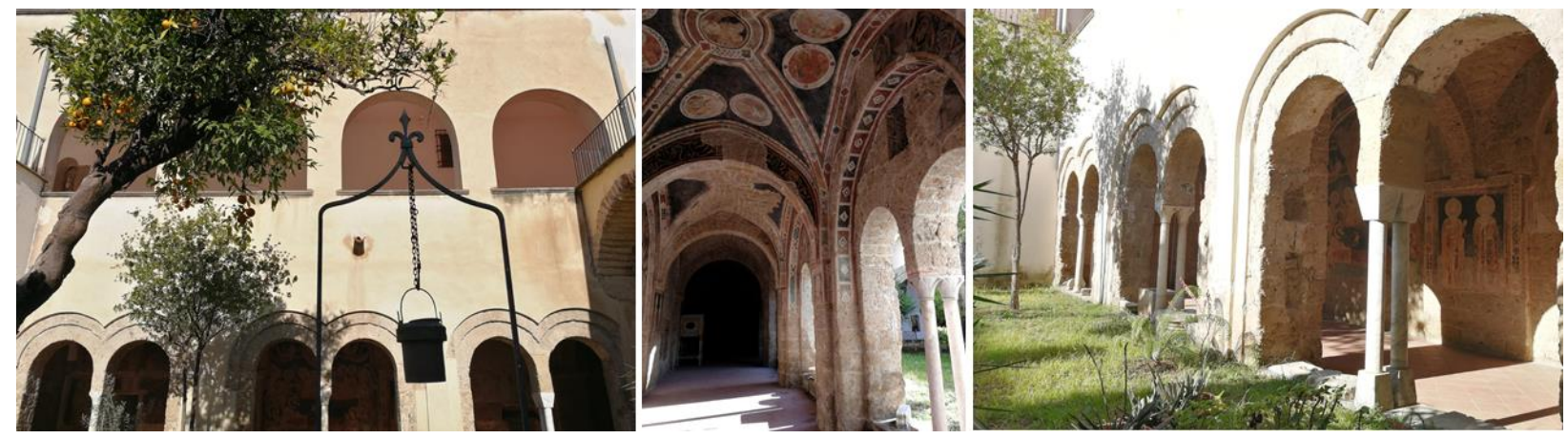

Figure 3. Cloister of San Francesco, Aversa.

Another important cloister in Aversa is the fourteenth-century medieval cloister of San Domenico that develops parallel to the southern side of the homonymous church. It is defined by square plan with acute vaults on pillars and pointed arches.

The Gothic cloister of Sant'Antonio reconfigured in the eighteenth century is dominated in the southeastern corner by the late Romanesque bell tower, in blocks of yellow tuff (Fiengo \& Guerriero, 2002).

The cloister of the Announced belongs to the homonymous Real Casa (De Falco, 2018) an historical building divided into several rooms erected in various periods by some of the most renowned Neapolitan architects. The cloister is defined by a rectangular system with a double row of arches on pillars and it is characterized by the presence of fruit trees.

Well known are also the cloisters of the abbey of San Lorenzo ad Septimum. The minor cloister built in the late fifteenth century has a quadrangular plan and presents a succession of arches supported by pillars, arched windows and baroque stucco decorations. Today is still possible to admire the two columns of the marble well originally placed in the center. On the other side the major cloister was built at the end of the sixteenth century by local craftsmen probably based on a project by the Florentine architect Giovan Antonio Dosio. The planimetric layout is rectangular with two rows of pointed arch on marble columns but miss of green and blue elements (Jacazzi, 2018).
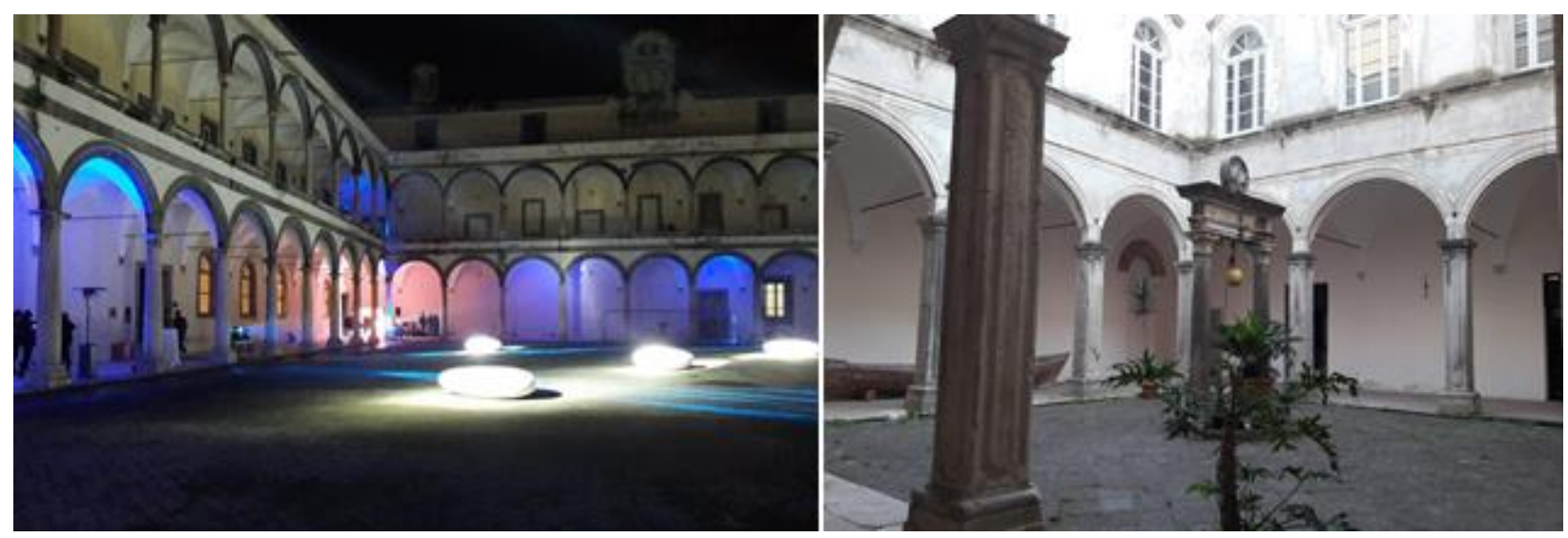

Figure 4. Major and Minor Cloister of San Lorenzo, Aversa.

\section{The restorative potential of sacred architectures}

With growing population and building structures is not easy find de-stressing places or create new ones. For these reasons in last years there has been a considerable rise in global interest to the role and importance of the healing places. As, in most overcrowded cities, is more and more difficult to find green oases, new solutions for people wellbeing have been proposed and adopted by architects and urban planners. For example, in the mega city of Tehran (Pouya, 2017) roof gardens are becoming a common trend where visitors and citizens can escape from stressful everyday life and find a pleasant space where spend their spare time.

Sacred architectures have a great potential as restorative environment. The results of several studies focused on spiritual retreats (Ouellette et al., 2005) (Gill, 2018) or simply on the frequentation of places of worship (Herzog, 
2010) (Fujiwara et al., 2014) proved that they can positively impact on the human health, with bigger effects on sick rather than healthy people.

Among the different religious architectures, the cloisters seem to fulfill all that positive requirements, natural and architectural-cultural, that makes indoor or outdoor spaces suitable to be used for the people well-being.

The studies carried out in recent years at the cloisters of the old city center of Naples (Fernandez et al., 2014) (Maffei et al., 2017, 2018) shows how these spaces can be possible alternative to urban green parks. These studies, conducted on 9 different cloisters (Cloister of San Gregorio Armeno, Cloister of Saint Domenico Maggiore, Cloister of San Giovanniello, Cloister of Santa Patrizia, Cloister of Sant'Andrea delle Dame, Cloister of Saints Marcellino e Festo, Cloister of the Santi Apostoli, Cloister of Girolamini and Cloister of Santa Maria delle Grazie) between the 2014 and 2018, have analyzed the existing noise: along 2 different urban paths to and from 2 opposite surrounding trafficked places, and inside the cloisters. Several binaural recordings were carried out during different day periods and, in some case, repeated along the years, allowing to describe properly the spatial and the temporal variability of the surrounding urban soundscape and of the cloisters.

Results highlighted that among paths the A-weighted sound equivalent levels that describe the urban noise, ranged from 66.7 to $73.7 \mathrm{~dB}(\mathrm{~A})$ while 90th percentile from 50.3 and $64.3 \mathrm{~dB}(\mathrm{~A})$. On the other hand, the A-weighted sound equivalent levels within cloisters ranged from 50.2 to $62.6 \mathrm{~dB}(\mathrm{~A})$ with the background noise between from 40.4 and $56.1 \mathrm{~dB}(\mathrm{~A})$. In average the A-weighted sound equivalent levels inside the cloisters were about $14 \mathrm{~dB}$ lower the surrounding noise, up to about $22 \mathrm{~dB}$ for Cloister of Girolamini. Lowest differences were measured at the cloisters of San Giovanniello $(11.1 \mathrm{~dB})$ and Sant'Andrea delle Dame $(10.6 \mathrm{~dB})$, both hosting the headquarters of the academic institutions. An assessment of the qualitative aspects of the cloisters showed that all the cloisters present entrances protected from outdoor by large doors or thick arcs which shelter, and all have elements of significant cultural value. Although 5 of them host educational activities are then freely accessible for tourists and citizens as well as the other 4 cloisters. Greenery exists in all cloisters while water elements only in 4.

The recent subjective survey carried out on 35 people visited three of the previous cloisters (Cloister of San Giovanniello, Cloister of Sant'Andrea delle Dame, Cloister of Saints Marcellino e Festo) has highlighted that 36,7\% of the interviewed people already used the cloisters as quiet areas, while the $14,3 \%$ were in search of more private places and $16,7 \%$ of green areas. In addition, the cultural value of the places was considered "an attractor" for the $23,8 \%$ of interviewed people.

\section{Conclusions}

The studies carried out in last years on cloisters have highlighted how part of these sites are already used by local inhabitants and tourists as peaceful places, because they host greenery and cultural elements or because they represent spaces for mental and physical escaping from the surrounding urban environment.

Although these potentialities, today most of them are unknown by lots of people that live and visit the historical city center of Naples. A systematic identification and classification of the characteristics of these sites is necessary.

Interactive maps and local multiphysics monitoring systems (e.g. crowding, noise levels, sunlight) could help citizens and tourists to discover and enjoy the benefit of these sites.

\section{References}

Alt, P. L. (2017) Sacred space and the healing journey. Ann Palliat Med, 6, 284-296. doi: 10.21037/apm.2017.06.09

Costa, M. R. (1996). I chiostri di Napoli. Roma, Italia: Newton \& Compton.

De Bell, S., Graham, H., Jarvis, S. \& White, P. (2017). The importance of nature in mediating social and psychological benefits associated with visits to freshwater blue space. Landscape and Urban Planning, 167, 118-127. doi: 10.1016/j.landurbplan.2017.06.003

De Falco, C. (2018). Dipartimento di Ingegneria. La Real Casa dell'Annunziata di Aversa. In Università degli Studi della Campania Luigi Vanvitelli (pp. 213 -223). Napoli, Italia: Giannini Editore.

Dodd, J. \& Jones, C. (2014). Mind, body, spirit: How museums impact health and wellbeing. Leicester, United Kingdom: Research Centre for Museums and Galleries. 


\section{Maffei / Proceedings of Science and Technology}

Fernández, D., Pascale, A., Masullo, M., Maffei, L. \& Puyana, V. (2014, October). The value of the cloisters in Naples’ historical city centre as quiet and restorative places. Proceedings of $45^{\circ}$ Congreso Español de Acústica $-8^{\circ}$ Cong. Ibérico de Acústica. Murcia, Spain.

Fiengo, G. \& Guerriero, L. (2002). Il centro storico di Aversa. Napoli, Italia: Arte Tipografica Editrice.

Fujiwara, D., Cornwall, T. \& Dolan, P. (2014). Heritage and Wellbeing. London, United Kingdom: English Heritage.

Gill, C., Packer, J. \& Ballantyne, R. (2018). Exploring the restorative benefits of spiritual retreats: the case of clergy retreats in Australia. Tourism Recreation Research, 43, 235-249. doi:10.1080/02508281.2017.1410972

Herzog, T. R., Ouellette, P., Rolens, J. R. \& Koenigs, A. M. (2010). Houses of worship as restorative environments. Environment and Behavior, 42, 395-419. doi: 10.1177/0013916508328610

Horn, W. (1973). On the Origins of the Medieval Cloister. Gesta, 12, 13-52. doi: 10.2307/766633

Jacazzi, D. (2018). Dipartimento di Architettura e Disegno Industriale. La Badia di San Lorenzo “extra Muros Aversae”. In Università degli Studi della Campania Luigi Vanvitelli (pp. 193-205). Napoli, Italia: Giannini Editore.

Keniger, L. E., Gaston, K. J., Irvine, K. N. \& Fuller, R. A. (2013). What are the benefits of interacting with nature? International Journal of Environmental Research and Public Health, 10, 913-935. doi:10.3390/ijerph10030913

Maffei, L., Masullo, M. \& Oliviero, A. (2017, August). Quiet areas inside historical city centers. Proceedings of Internoise 2017. Hong Kong, China.

Maffei, L., Toma, R. A. \& Masullo, M. (2018, August). Objective and subjective assessment of pockets of quiet inside historical urban areas. Proceedings of Internoise 2018. Chicago, Illinois.

Mallarach, J. M. (2014). Poblet Monastery cloister garden on the Al-Andalus border: aims and meaning of the restoration work. Retrieved from http://themathesontrust.org/

Ouellette, P., Kaplan, R. \& Kaplan, S. (2005). The monastery as a restorative environment. Journal of Environmental Psychology, 25, 175-188. doi: 10.1016/j.jenvp.2005.06.001

Ponzetti, J. J. (2014). Governance in the Cloister: Lessons from the Rule of Benedict for Sustainable Leadership in Communal Organizations. Journal of Leadership, Accountability and Ethics, 11, 25-35.

Pouya, S. (2017). Healing Gardens in the Mega Cities; Example of Tehran. Journal of Urban Academy, 10, 139-156.

Riva, M. A. \& Cesana, G. (2013). The charity and the care: the origin and the evolution of hospitals. European Journal of Internal Medicine, 24, 1-4. doi: 10.1016/j.ejim.2012.11.002

Rodrigues, A. D. (2015). Beyond contemplation, the real functions held at the cloisters. In A. D. Rodrigues, A. Perla, D. Parras (Eds), Cloisters Gardens, Courtyards and Monastic Enclosures (pp.13 -35). Évora, Portugal: CHAIA/CIUHCT. 